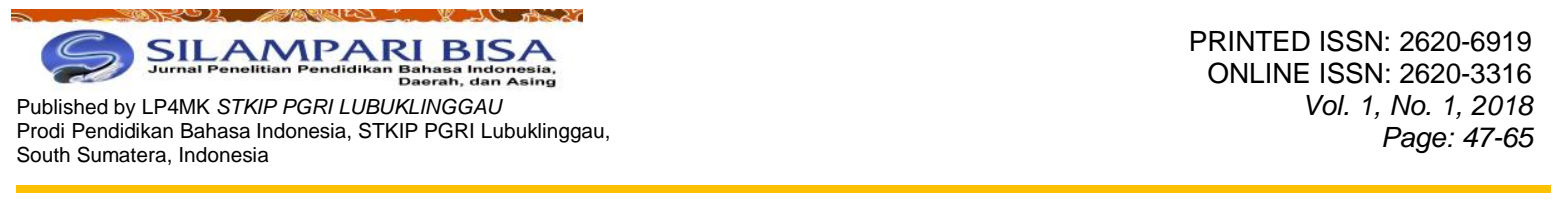

\title{
ALIH KODE DAN CAMPUR KODE DALAM PENGAJARAN BAHASA INDONESIA KELAS XI SMAN 6 KABUPATEN BENGKULU TENGAH
}

\author{
Ira Yuniati \\ FKIP Universitas Muhammadiyah Bengkulu \\ JIn. Bali, Kampung Bali, Teluk Segara, Kota Bengkulu, 38119, Indonesia \\ Email: irayuniati72@yahoo.co.id
}

Submitted: 24-May-2018

Accepted : 26-June-2018
Published: 26-June-2018

DOI: 10.31540/silamparibisa.v1i1.14

URL: https://doi.org/10.31540/silamparibisa.v1i1.14

\begin{abstract}
Abstrak
Tujuan penulisan dari penelitian ini adalah untuk memperoleh data empiris tentang beberapa aspek alih kode dan campur kode, dan mencari penyebab terjadinya alih kode dan campur kode yang terdapat di dalam pengajaran bahasa Indonesia di kelas XI SMAN 6 Kabupaten Bengkulu Tengah. Penelitian ini merupakan penelitian kualitatif dengan teknik analisis isi (content analysis) dengan pendekatan sosiolinguistik. Pengumpulan data dilakukan melalui observasi, catatan membaca buku-buku, data internet, jurnal, yang berhubungan dengan objek penelitian terutama ilmu sosiolinguistik yang menjelaskan tentang alih kode dan campur kode. Lalu transkripsi tersebut diteliti berdasarkan teori yang ada, kemudian diklasifikasi dengan melakukan wawancara kepada guru yang bersangkutan. Dari hasil temuan penelitian dan pembahasan, diketahui alasan guru menggunakan alih kode dan campur kode pada pengajarannya, antara lain karena: (1) guru berusaha untuk mendefinisikan kembali situasi yang telah disebutkan sebelumnya (redefinition) agar siswa lebih memahami maksud dari ucapannya, (2) guru berusaha mencairkan suasana kelas yang monoton dengan menggunakan alih kode dan campur kode untuk menimbulkan kesan lucu, dan (3) guru harus mempertegas perintahnya (strengthen command) agar siswa lebih mengerti bahwa hal yang diperintahkan guru harus diikuti. Gejala sosial yang mendasari banyak atau sedikitnya kasus alih kode dan campur kode dalam pengajaran bahasa Indonesia adalah tingkat kemampuan berbahasa dari guru yang mengajarkan bahasa tersebut. Semakin tinggi kemampuan berbahasanya, maka akan semakin sedikit kasus alih kode itu terjadi, begitu juga sebaliknya.
\end{abstract}

Kata kunci: alih kode, campur kode, pengajaran bahasa Indonesia

\section{CODE SWITCHING AND CODE MIXING IN TEACHING INDONESIAN LANGUAGE CLASS XI SMAN 6 MIDDLE SUB-PROVINCE BENGKULU}

\begin{abstract}
The objective of this research was to obtain get empirical data about some aspect displace code and mingle code, and describe factors which was happening of code switching and code mixing. This research represented qualitative method with content analysis technique by using sociolinguistics approach. Data collecting technique was done through observation, note book, internet, journal, related to research object especially sosiolinguistics science explaining about code switching and code mixing. From result of investigation, it was found out that there were some reasons why teachers did code switching and code mixing. They were: (1) teachers define again
\end{abstract}


situation that have been mentioned previously redefinition to be student more is comprehending of intention from its utterance, (2) teachers try to liquefy class atmosphere which monoton by using displacing code and mingle code to evoke humorous impression, and (3) the teacher must reinforce his command (strengthen command) so that students better understand that what the teacher instructed must be followed. The social phenomenon that underlies many or at least cases of code transfers and code mixes in Indonesian language teaching is the level of language skills of the teachers who teach the language. The higher the language capability, the less cases of code change occur, and vice versa.

Keywords: code switching, code mixing, teaching Indonesian language

\section{A. Pendahuluan}

Era globalisasi dan pasar bebas mau tidak mau telah terjadi di seluruh dunia termasuk di Indonesia. Persaingan di seluruh aspek semakin berat, terutama di aspek lapangan kerja dan semakin sulit karena tidak adanya batasan yang akan membatasi orang-orang dari seluruh dunia untuk masuk dan mencari lapangan pekerjaan ke negara manapun yang mereka inginkan, termasuk Indonesia.

Dalam persaingan tersebut, pada akhirnya dibutuhkan alat komunikasi yang efektif agar tidak terjadi ketimpangan dan mispersepsi, dan alat tersebut adalah bahasa. Finegan (2004:27) mengatakan ada dua pengertian dasar bahasa. Pertama bahasa adalah suatu sistem yang sangat kompleks yang dapat dikuasai oleh anak-anak dalam waktu singkat. Kedua, bahasa adalah sistem lambang yang arbitrer.

Dari dua pengertian itu, dapat disimpulkan bahwa bahasa adalah suatu sistem lambang yang arbitrer yang dapat dikuasai oleh anak-anak dalam waktu singkat, baik dengan pemerolehan secara alami maupun dengan pembelajaran. Tidak dapat dipungkiri, di dunia terdapat banyak masyarakat bahasa. Masyarakat bahasa ini bertemu dan hidup bersama. Sulit menemukan masyarakat yang benar-benar monolingual karena tidak ada kelompok bahasa yang terpisah dari kelompok bahasa yang lain. Menurut Wardhaugh (2002:95), seorang yang monolingual akan berusaha meningkatkan kemampuan bahasanya dengan mempelajari bahasa lain, agar bisa berkomunikasi dengan masyarakat yang bahasanya berbeda.

Pada saat ini, sudah menjadi suatu hal yang biasa jika dalam kehidupan sehari-hari seseorang menggunakan lebih dari satu bahasa. Kadang penutur 
menggunakan satu bahasa di rumah, lalu menggunakan bahasa lainnya di kantor atau sekolah. Bahkan kadang menggabungkan beberapa bahasa di satu tempat. Seseorang yang bilingual harus mengetahui bahwa setiap masyarakat memiliki variasi bahasa (codes) yang memiliki aturan-aturan tertentu. Seseorang yang bilingual harus mengetahui dengan siapa, untuk apa, dan situasi bagaimana yang mendukung penutur untuk bisa menggunakan bahasa yang berbeda, karena pilihan bahasa yang penutur lakukan itu akan menunjukkan identitas sosialnya. Pada saat seseorang melakukan pilihan bahasa yang akan dia gunakan yang disesuaikan dengan situasi tersebut itulah, maka dia akan melakukan pergantian bahasa. Pergantian bahasa inilah yang sering disebut alih kode (code switching). Namun, seseorang dapat pula menggunakan unsur-unsur dari satu bahasa, sementara ia sedang berbicara dalam bahasa yang lain. Hal ini biasa disebut campur kode (code mixing) (Koentjono: 1990:125).

Definisi alih kode dan campur kode telah banyak diberikan oleh para ahli sosiolinguistik, salah satunya adalah Fasold (1984:208) dalam bukunya The Sosiolinguistics of Society. la mengatakan bahwa bila pilihan mungkin terjadi pada satu bahasa atau lebih tergantung pada situasi, maka ia telah melakukan alih kode, dan apabila seseorang menggunakan satu elemen dari suatu bahasa sementara dia sedang bicara dalam bahasa lain atau berada dalam satu sistem bahasa, maka ia telah melakukan campur kode. Alih kode menurut Suwandi (2010:86) dapat terjadi dalam sebuah percakapan, ketika seorang pembicara menggunakan sebuah bahasa dan mitra bicaranya menjawab dengan bahasa lain. Bloom \& Gumperz (dalam Sgall: 1992:18) juga berpendapat bahwa alih kode adalah perubahan dua sistem gramatikal atau sub-sistem bahasa dalam satu situasi yang sama atau setara. Dalam catatannya, mengenai alih kode antara dialek lokal dengan dialek formal bahasa Jerman, Bloom \& Gumperz (dalam Sgall, 1992:18) mengaitkan alih kode dengan beragam bidang sosial (agama, politik, ekonomi, dan sebagainya), tetapi semuanya bergantung pada bagiannya masingmasing, misalnya: persahabatan yang dekat dan terbuka.

Selain Bloom \& Gumperz (dalam Coulmas (2005:110), juga menjelaskan bahwa allih kode (code switching) terjadi saat pembicara menyadari bahwa dia memiliki dua varietas bahasa atau lebih dan bisa memisahkan keduanya secara 
baik, meskipun mereka mungkin tidak terbiasa atau tidak terus-menerus melakukan peralihan. Masih menurut Coulmas (2005:110), alih kode diartikan sebagai pengontrolan strategi, pembeda antara unsur leksikal yang asli dan leksikal pinjaman dalam satu percakapan yang sama.

Kaum imigran adalah contoh masyarakat yang sering melakukan campur kode. Mereka menggunakan banyak bahasa baru dalam bahasa asli mereka, bahkan mereka berbicara menggunakan banyak bahasa untuk mengetahui bahasa baru. Kasus alih kode dan campur kode dapat terjadi secara spontanitas tergantung pada situasi atau penyebab lain yang membuat seseorang yang sedang berdialog dengan orang lain melakukan alih kode atau campur kode. Misalnya, Andi sedang bercakap-cakap dengan Budi di kantin dengan bahasa Bengkulu, karena memang keduanya berasal dari Bengkulu, lalu tiba-tiba datang Ani yang tidak dapat berbicara bahasa Bengkulu, secara spontan Andi mengganti bahasanya dengan bahasa Indonesia agar Ani paham dengan apa yang mereka bicarakan. Fenomena inilah yang disebut switching code. Dalam percakapan itu pula, terkadang Andi juga menggunakan beberapa istilah dalam bahasa Bengkulu saat dia bicara bahasa Indonesia. Fenomena inilah yang disebut mixing code.

Fenomena alih kode dan campur kode ini banyak kita temui dalam kehidupan sehari-hari, baik dalam bahasa lisan maupun dalam bahasa tulisan (ilmiah dan non-ilmiah). Beberapa penelitian tentang alih kode dan campur kode dalam bahasa lisan yang telah dilakukan oleh para ahli linguistik, misalnya: pada tahun 1972, Bloom dan Gumperz yang telah meneliti peralihan kode pada masyarakat Hemnesberget di Norwegia. Lalu pada tahun 1992, Peter Sgall, Jiri Hronek, Alexandr Stich, dan Jan Horecky yang telah meneliti alih kode dalam masyarakat Ceko. Masih banyak lagi penelitian tentang alih kode dan campur kode.

Tokoh linguistik yang membedakan istilah alih kode dan campur kode adalah McLaughlin (dalam Hoffmann, 1991:110), dia mengemukakan alih kode sebagai perubahan bahasa dalam bentuk satu frase atau dalam satu kalimat bertingkat, sedangkan campur kode adalah perubahan bahasa terjadi dalam satu kalimat dan umumnya terjadi dalam satu leksikal. Saville-Troike (2003:68) 
mengemukakan 12 fungsi alih kode dan campur kode serta pergeseran bahasa, yaitu: (1) identifikasi kelompok (group identification), (2) solidaritas (solidarity), (3) penjaga jarak (distancing), (4) pendefinisian kembali situasi yang telah disebutkan (redefinition of a situation have already been mentioned), (5) memperhalus atau mempertegas permintaan atau perintah (soften or strengthen request or command), (6) mengatakan sesuatu dua kali dalam bahasa yang berbeda dengan tujuan untuk mempertegas atau menghilangkan keambiguan (saying something twice in different languages in order to intensify or eliminate ambiguity), (7) menimbulkan kesan lucu atau untuk menunjukkan bahwa suatu pernyataan yang menjatuhkan tidak perlu dianggap serius (humorous effect or to indicate that a referentially derogatory comment is not to be taken seriously), (8) kutipan langsung (direct quotation), (9) pernyataan yang bersifat ideologis (ideological statement), (10) kebutuhan leksikal (lexical need), (11) mengasingkan seseorang dari pembicaraan jika suatu pernyataan ditujukan hanya terbatas pada orangorang tertentu (to exclude other people within hearing if a comment is intended for only a limited audience), dan (12) strategi perbaikan atau korelasi yang dilakukan ketika penutur menyadari bahwa ia telah menggunakan kode yang tidak tepat (repair strategy when the speakers realize they have been using an inappropriate code).

Di Indonesia fenomena alih kode dan campur kode antara bahasa Indonesia dan bahasa daerah masih sering terjadi. Fenomena ini dapat dilihat dari berbagai aspek, salah satunya adalah dalam pengajaran bahasa Indonesia di sekolah-sekolah. Sebagaimana penelitian yang pernah dilakukan oleh Rulyandi \& Sulistyo (2014) yang tertulis dalam jurnal Paedagogia, Vol. 17 No. 1 Tahun 2014 dengan judul Alih Kode dan Campur Kode dalam Pembelajaran Bahasa Indonesia di SMA. Penelitian ini mengkaji tentang wujud alih kode dan campur kode yang terjadi dalam pembelajaran bahasa Indonesia dan faktor-faktor penyebab terjadinya alih kode dalam pembelajaran bahasa Indonesia. Hampir sama dengan penelitian sebelumnya, dalam penelitian ini, peneliti mengkaji tentang alih kode dan campur kode yang terjadi dalam pengajaran bahasa Indonesia di SMAN 6 kelas XI Kabupaten Bengkulu Tengah. Dari hasil penelitian ini, diharapkan dapat bermanfaat dalam pengembangan ilmu pengetahuan di bidang sosiolinguistik 
terutama tentang alih kode dan campur kode. Selain itu, dapat dijadikan bahan masukan dalam pengembangan pengajaran bahasa Indonesia di sekolah.

\section{B. Metode Penelitian}

Penelitian ini merupakan penelitian kualitatif dengan teknik analisis isi (content analysis) dengan pendekatan sosiolinguistik. Penelitian ini difokuskan pada tuturan guru yang menggunakan alih kode dan campur kode saat berinteraksi dengan siswa dalam pengajaran bahasa Indonesia di Kelas XI SMAN 6 Kabupaten Bengkulu Tengah. Subfokus dari penelitian ini, yaitu klasifikasi alih kode dan campur kode, jenis-jenis alih kode dan campur kode, dan fungsi alih kode dan campur kode.

Objek penelitian ini adalah suara guru saat berinteraksi dengan siswa dalam pengajaran bahasa Indonesia di Kelas XI SMAN 6 Kabupaten Bengkulu Tengah. Teknik pengumpulan data dilakukan melalui: observasi, catatan dan membaca buku-buku, data internet, serta jurnal yang berhubungan dengan objek penelitian terutama ilmu sosiolinguistik yang menjelaskan tentang alih kode dan campur kode. Lalu transkripsi tersebut diteliti berdasarkan teori yang ada, kemudian diklasifikasi dengan melakukan wawancara kepada guru yang bersangkutan. Data dianalisis secara kualitatif, langkah-langkah yang dilakukan mencakup: pengumpulan data, reduksi data, penampilan data, penafsiran data, penarikan kesimpulan.

\section{Hasil Penelitian dan Pembahasan}

\section{Hasil Penelitian}

a. Pembelajaran Hari Pertama

1) Transkripsi Fonemis Pembelajaran Hari Pertama

Pada pengajaran hari pertama akan dianalisis tujuh ujaran guru yang mengandung alih kode dan campur kode. Kasus alih kode dan campur kode pada tiap-tiap ujaran tersebut ditulis dengan huruf miring dan digaris bawah. Berikut adalah transkripsi fonemis tersebut:

1) Mungkin itu saja materi pelajaran kita hari ini. Ngerti nidaw kaba ni? ngantuk sajaw (Mengerti tidak kamu ini? Mengantuk saja.). 
2) Berita itu terdiri dari beberapa jenis. Ada berita kriminal, ada berita faktual dan ada yang berisi hiburan. Dalam membaca berita intonasi suara harus jelas. Ndik bulih suarau putus-putus, kelaw kaba mbacaunyo, beee...riii..taaaa haa...ri...iiiii ni... (Tidak boleh suaranya putus-putus, nanti kalian membacanya, beee...riii...taa haaaa...riii...i...niii). Baca berita harus jelas, singkat, dan padat informasinya.

3) Dalam pelajaran bahasa Indonesia itu, ada membaca berita, membaca puisi, membaca cerita. Masing-masing_ndik samaw (tidak sama), punya ciri yang berbeda.

4) Siapa yang bisa menjawab pertanyaan pertama? Saya bu....saya bu...kelow kudai (nanti dulu), satu-satu gantian.

5) Ada yang mau bertanya? Ndik adaw yang betanyau? (Tidak ada yang bertanya?) Kalau begitu ibu yang bertanya?

6) Untuk pertemuan selanjutya, cari contoh berita, boleh dibaca berdua secara pasangan atau sendiri-sendiri. Bulih beritaw apaw sajaw yang penting beritaw (Boleh berita apa saja, yang penting berita).

7) Baiklah kalau ndik (tidak) ada yang bertanya, Ibu akhiri pertemuan hari ini. Assalamualaikum. Wr. Wb.

(a) Klasifikasi Alih Kode dan Campur Kode Ujaran Guru Hari Pertama

Pada hari pertama penulis menemukan tujuh kasus alih kode dan campur kode. Lalu setelah diklasifikasikan berdasarkan beberapa teori, penulis menemukan empat kasus alih kode dan tiga kasus campur kode.

Tabel 1. Klasifikasi Alih Kode dan Campur Kode Hari Pertama

\begin{tabular}{cc}
\hline Klasifikasi & Jumlah \\
\hline Alih Kode & 4 \\
\hline Campur Kode & 3 \\
\hline
\end{tabular}

Dari data di atas, dapat dilihat bahwa guru lebih dominan menggunakan alih kode $(57,14 \%)$ dari pada campur kode $(42,86 \%)$ pada hari pertama ini. Contoh dari kasus alih kode pada hari pertama dapat dilihat pada kalimat yang dapat dilihat pada transkripsi fonemis di atas, yaitu pada kalimat (1), (2), (5), dan (6), sementara contoh kalimat yang tergolong dalam campur kode dapat dilihat pada kalimat (3), (4), dan (7).

Pada kalimat (1), (2), (5), dan (6) sesuai dengan yang dikatakan oleh Fasold, jika satu klausa disusun berdasarkan tata bahasa dari satu bahasa dan klausa berikutya disusun berdasarkan tata bahasa yang lain terjadilah alih kode. 
Pada data (1), (2), (5), dan (6) setelah guru mengucapkan satu kalimat bahasa Indonesia, guru lalu beralih menggunakan kalimat dengan tata bahasa daerah, yaitu:

Ngerti nidaw kaba ni? ngantuk sajaw (Mengerti tidak kamu ini? Mengantuk saja). (1)

Ndik bulih suarau putus-putus, kelaw kaba mbacaunyo, beee...riii..taaaa haa...ri...iiiii ni... (Tidak boleh suaranya putus-putus, nanti kalian membacanya, beee...riii...taa haaaa...riii...i...niii). (2)

Ndik adaw yang betanyau? (Tidak ada yang bertanya?) (5)

Bulih beritaw apaw sajaw yang penting beritaw (Boleh berita apa saja, yang penting berita). (6)

Maka pada data (1), (2), (5), dan (6) guru telah menggunakan alih kode. Sementara pada kalimat (3), (4), dan (7) terlihat bahwa guru mencampurkan

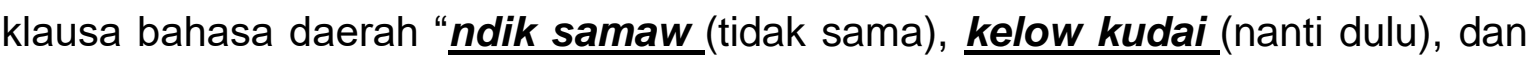
ndik (tidak)" saat sedang menggunakan satu kalimat utuh dalam bahasa Indonesia.

(b) Jenis Alih Kode dan Campur Kode Hari Pertama

Dari delapan kasus alih kode yang telah diklasifikasikan, pada hari pertama, penulis menemukan data sebagai berikut.

Tabel 2. Jenis-Jenis Alih Kode Hari Pertama

\begin{tabular}{lc}
\hline \multicolumn{1}{c}{ Jenis Alih Kode } & Jumlah \\
\hline Situational Switching & 3 \\
\hline Metaphrorical Switching & 1 \\
\hline
\end{tabular}

Pada hari pertama, guru beralih kode karena adanya perubahan situasi, tetapi tidak terjadi perubahan topik (situational switching) sebanyak 3 kali (75\%). Sementara guru beralih kode karena adanya perubahan topik pembicaraan (metaphrorical switching) sebanyak 1 kali (25\%). Contoh dari situational switching adalah kalimat yang terdapat pada kalimat (2), (5), dan (6) dan contoh metaphrorical switching dapat dilihat pada kalimat (1) di bawah ini.

Contoh metaphrorical switching:

Mungkin itu saja materi pelajaran kita hari ini. Ngerti nidaw kaba ni? ngantuk

sajaw (Mengerti tidak kamu ini? Mengantuk saja). 
Contoh dari situational switching:

Berita itu terdiri dari beberapa jenis. Ada berita kriminal, ada berita faktual dan ada yang berisi hiburan. Dalam membaca berita intonasi suara harus jelas. Ndik bulih suarau putus-putus, kelaw kaba mbacaunyo, beee...riii..taaaa haa...ri...iiiii ni... (Tidak boleh suaranya putus-putus, nanti kalian membacanya, beee...riii...taa haaaa...riii...i...niii). Baca berita harus jelas, singkat, dan padat informasinya.

Ada yang mau bertanya? Ndik adaw yang betanyau? (Tidak ada yang bertanya?) Kalau begitu ibu yang bertanya?

Untuk pertemuan selanjutya, cari contoh berita, boleh dibaca berdua secara pasangan atau sendiri-sendiri. Bulih beritaw apaw sajaw yang penting beritaw (Boleh berita apa saja, yang penting berita).

Pada data (2) guru menggunakan alih kode, tetapi masih membahas seputar bagaiamana cara seorang pembaca berita dengan suara yang jelas, hanya terjadi perubahan alih kode dari bahasa Indonesia ke bahasa daerah, maka jenis alih kode yang digunakan adalah situational switching. Sementara pada data (1), guru terlihat menggunakan metaphrorical switching, karena saat menyadari siswa kurang memperhatikan penjelasannya, siswa tersebut terlihat mengantuk saat guru sedang bertanya. Guru melakukan peralihan bahasa, dari bahasa resmi menjadi bahasa daerah ringan sebagai lelucon untuk kembali menyemangati siswa.

(c) Fungsi Alih Kode dan Campur Kode Pembelajaran Hari Pertama

Dari dua belas fungsi alih kode dan campur kode, penulis hanya menemukan tiga fungsi (alasan) alih kode dan campur kode yang digunakan oleh guru pada hari pertama, yaitu:

Tabel 3. Fungsi-Fungsi Alih Kode dan Campur Kode Hari Pertama

\begin{tabular}{clc}
\hline No. & \multicolumn{1}{c}{ Fungsi Alih/Campur Kode } & Jumlah \\
\hline 1 & Menimbulkan kesan lucu & 2 \\
\hline 2 & Pendefinisian kembali & 4 \\
\hline 3 & Mempertegas perintah & 1 \\
\hline
\end{tabular}

Melihat data di atas, dapat dilihat bahwa saat menggunakan alih kode dan campur kode, guru memang sengaja melakukannya. Guru selalu mempunyai alasan (fungsi) yang pasti saat menggunakan alih kode dan campur kode pada hari pertama ini. Hal ini dapat dilihat dari contoh di bawah ini: 
(1)Mungkin itu saja materi pelajaran kita hari ini. Ngerti nidaw kaba ni? ngantuk sajaw (Mengerti tidak kamu ini? Mengantuk saja).

(2) Berita itu terdiri dari beberapa jenis. Ada berita kriminal, ada berita faktual dan ada yang berisi hiburan. Dalam membaca berita intonasi suara harus jelas. Ndik bulih suarau putus-putus, kelaw kaba mbacaunyo, beee...riii..taaaa haa...ri...iiiii ni... (Tidak boleh suaranya putus-putus, nanti kalian membacanya, beee...riii...taa haaaa...riii...i...niii). Baca berita harus jelas, singkat, dan padat informasinya.

(6) Untuk pertemuan selanjutya, cari contoh berita, boleh dibaca berdua secara pasangan atau sendiri-sendiri. Bulih beritaw apaw sajaw yang penting beritaw (Boleh berita apa saja, yang penting berita).

Pada data (1), penulis melihat usaha guru ketika melihat suasana kelas yang kurang kondusif dan kurang antusias terhadap pelajaran. Maka, guru berupaya melakukan sesuatu yang bisa menghibur siswa agar tidak bosan dengan suasana kelas atau dapat disamakan dengan fungsi menimbulkan kesan lucu dan tidak perlu dianggap serius, yaitu dengan menggunakan contoh daari ujaran sebelumnya dalam lelucon bahasa daerah.

Pada data (2), alih kode pada ujaran guru ini berfungsi sebagai cara guru untuk melakuka pendefinisian kembali situasi yang telah disebutkan agar siswa mengerti apa yang guru jelaskan tentang bagaimana cara menjadi pembeca berita dengan suara yang baik. Pada data (8), meskipun sekilas terlihat seperti terjadi secara spontan, namun telah dianalisis dan dikonfirmasi pada guru yang bersangkutan, ternyata campur kode yang digunakan oleh guru ini berfungsi untuk mempertegas perintah.

b. Pembelajaran Hari Kedua

1) Transkripsi Fonemis Pengajaran Hari Kedua

Pada pengajaran hari kedua akan dianalisis empat ujaran guru yang mengandung alih kode dan campur kode. Kasus alih kode dan campur kode pada tiap-tiap ujaran tersebut ditulis dengan huruf miring dan digaris bawah. Berikut adalah transkripsi fonemis tersebut:

1) Assalamualaikum. Wr. Wb. Sapaw yang ndik hadir hari nie? (Siapa yang tidak hadir hari ini?) 
2) Baiklah sesuai tugas pertemuan sebelumnya, yang mana ibu meminta tiap kalian untuk membawa berita, ada yang ndik (tidak) bawa berita?

3) Sapaw (siapa) yang mau memberi komentar terhadap penampilan Agus dan Doni, bagaimana suara mereka dalam membaca berita?

4) Baiklah kalau ndik (tidak) ada yang bertanya, ibu akhiri pertemuan hari ini. Assalamualaikum. Wr. Wb.

(a) Klasifikasi Alih Kode dan Campur Kode Ujaran Guru Hari Kedua

Pada hari kedua penulis menemukan empat kasus alih kode dan campur kode. Lalu setelah diklasifikasikan berdasarkan beberapa teori, penulis menemukan empat kasus alih kode dan tiga kasus campur kode.

Tabel 4. Klasifikasi Alih Kode dan Campur Kode Hari Kedua

\begin{tabular}{cc}
\hline Klasifikasi & Jumlah \\
\hline Alih Kode & 1 \\
\hline Campur Kode & 3 \\
\hline
\end{tabular}

Dari data di atas, dapat dilihat bahwa guru lebih dominan menggunakan campur kode $(75 \%)$ dari pada alih kode (25\%) pada hari kedua ini. Contoh dari kasus alih kode pada hari kedua dapat dilihat pada kalimat yang dapat dilihat pada transkripsi fonemis di atas, yaitu pada kalimat (1), sementara contoh kalimat yang tergolong dalam campur kode dapat dilihat pada kalimat (2), (3), dan (4). Pada kalimat (1), karena satu klausa disusun berdasarkan tata bahasa dari satu bahasa dan klausa berikutnya disusun berdasarkan tata bahasa yang lain terjadilah alih kode. Pada data (1) setelah guru mengucapkan satu kalimat bahasa Indonesia, guru lalu beralih menggunakan kalimat dengan tata bahasa daerah, yaitu:

Assalamualaikum. Wr. Wb. Sapaw yang ndik hadir hari nie? (Siapa yang tidak hadir hari ini?) (1)

Maka pada data (1), guru telah menggunakan alih kode. Sementara pada kalimat (2), (3), dan (4) terlihat bahwa guru mencampurkan klausa bahasa daerah " $\underline{\text { ndik }}$ (tidak), sapaw (siapa), dan ndik (tidak)" saat sedang menggunakan satu kalimat utuh dalam bahasa Indonesia.

(b) Jenis Alih Kode dan Campur Kode Hari Kedua

Dari delapan kasus alih kode yang telah diklasifikasikan, pada hari kedua, penulis menemukan data sebagai berikut: 
Tabel 5. Jenis-Jenis Alih Kode Hari Pertama

\begin{tabular}{lc}
\hline \multicolumn{1}{c}{ Jenis Alih Kode } & Jumlah \\
\hline Situational Switching & 1 \\
\hline Metaphrorical Switching & - \\
\hline
\end{tabular}

Pada hari kedua, guru beralih kode karena adanya perubahan situasi, tetapi tidak terjadi perubahan topik (situational switching) sebanyak 1 kali (100\%). Sementara, guru beralih kode karena adanya perubahan topik pembicaraan (metaphrorical switching) tidak terdapat pada pertemuan kedua ini. Contoh dari situational switching adalah kalimat yang terdapat pada kalimat (1) berikut ini:

1) Assalamualaikum. Wr. Wb. Sapaw yang ndik hadir hari nie? (Siapa yang tidak hadir hari ini?)

Pada data (1) guru menggunakan alih kode, tetapi masih membahas seputar pengucapan salam dan lanjut menanyakan siapa yang tidak hadir pada hari itu, hanya terjadi perubahan alih kode dari bahasa Indonesia ke bahasa daerah, maka jenis alih kode yang digunakan adalah situational switching.

(c) Fungsi Alih Kode dan Campur Kode Hari Kedua

Dari dua belas fungsi alih kode dan campur kode secara teori, penulis hanya menemukan tiga fungsi (alasan) alih kode dan campur kode yang digunakan oleh guru pada hari pertama, yaitu:

Tabel 6. Fungsi-Fungsi Alih Kode dan Campur Kode Hari Pertama

\begin{tabular}{clc}
\hline No. & \multicolumn{1}{c}{ Fungsi Alih/Campur Kode } & Jumlah \\
\hline 1 & Menimbulkan Kesan Lucu & 1 \\
\hline 2 & Pendefinisian Kembali & 3 \\
\hline
\end{tabular}

Melihat data di atas, dapat dilihat bahwa saat menggunakan alih kode dan campur kode, guru memang sengaja melakukannya. Guru selalu mempunyai alasan (fungsi) yang pasti saat menggunakan alih kode dan campur kode pada hari pertama ini. Hal ini dapat dilihat dari contoh di bawah ini:

(1) Assalamualaikum. Wr. Wb. Sapaw yang ndik hadir hari nie? (Siapa yang tidak hadir hari ini?)

(2) Baiklah sesuai tugas pertemuan sebelumnya, yang mana ibu meminta tiap kalian untuk membawa berita, ada yang ndik (tidak) bawa berita? 
Pada data (1), penulis melihat usaha guru untuk menarik perhatian siswa dan menimbulkan kesan akrab dengan siswa. Maka, guru berupaya melakukan sesuatu yang bisa menghibur siswa agar tidak bosan dengan suasana kelas atau dapat disamakan dengan fungsi menimbulkan kesan lucu dan tidak perlu dianggap serius, yaitu dengan menggunakan contoh daari ujaran sebelumnya dalam lelucon bahasa daerah. Pada data (2), (3), dan (4), meskipun sekilas terlihat seperti terjadi secara spontan, namun telah dianalisis dan dikonfirmasi pada guru yang bersangkutan, ternyata campur kode yang digunakan oleh guru ini berfungsi untuk memperjelas pernyataan berkenaan dengan tugas yang diberikan.

\section{Pembahasan}

Berdasarkan hasil penelitian, penulis mendapatkan 11 kasus alih kode dan campur kode pada dua hari pembelajaran. Dari 11 kasus yang diteliti, sebanyak 5 kasus (45,45\%) digolongkan dalam kasus alih kode dan yang termasuk campur kode sebanyak 6 kasus (54,54\%). Untuk memperjelas frekuensi munculnya allih kode dan campur kode pada dua hari pembelajaran bahasa Indonesia yang telah diteliti, penulis membaginya perhari lalu membuat diagram batang tentang penggunaan alih kode dan campur kode, yaitu sebagai berikut:

Tabel 7. Pengelompokkan Alih Kode dan Campur Kode

\begin{tabular}{lccc}
\hline & Hari 1 & Hari 2 & Jumlah \\
\hline Alih Kode & 4 & 1 & 5 \\
\hline Campur Kode & 3 & 3 & 6 \\
\hline
\end{tabular}

Seperti yang telah disebutkan sebelumnya, bahwa secara umum alih kode dapat diartikan sebagai terjadinya peralihan bahasa atau dialek dalam dua kalimat atau klausa yang berbeda dalam satu percakapan. Pada alih kode tidak terjadi gabungan unsur-unsur bahasa lain dalam dua bahasa yang digunakan. Misalnya pada kalimat di bawah ini:

Mungkin itu saja materi pelajaran kita hari ini. Ngerti nidaw kaba ni?

ngantuk sajaw (Mengerti tidak kamu ini? Mengantuk saja).

Ketika melihat situasi KBM yang terlihat tidak kondusif untuk meneruskan pembelajaran, guru melakukan sebuah strategi, yaitu dengan melakukan perubahan bahasa dari bahasa Indonesia ke dalam bahasa daerah. Setelah 
menggunakan kalimat panjang berbahasa Indonesia untuk menyatakan bahwa pelajaran hari ini akan segera berakhir, guru menggunakan kalimat "Ngerti nidaw kaba ni? ngantuk sajaw" (Mengerti tidak kamu ini? Mengantuk saja). Hal ini dilakukan untuk mencoba memberi hiburan dan sekaligus menyindir ke pemahaman siswa terhadap apa yang telah diajarkannya.

Dalam upaya tersebut, meskipun guru melakukan pergantian bahasa, namun saat melakukannya guru, sama sekali tidak mencampur satu struktur ataupun kosakata bahasa Indonesia dalam bahasa daerah atau sebaliknya dalam satu kalimat, melainkan dalam kalimat yang berbeda, maka berdasarkan teori Fasold (1984) ujaran guru ini dapat dikategorikan sebagai alih kode.

Data lain yang menunjukkan tentang penggunaan alih kode, juga dapat dilihat pada data (2) di bawah ini:

Berita itu terdiri dari beberapa jenis. Ada berita kriminal, ada berita faktual dan ada yang berisi hiburan. Dalam membaca berita intonasi suara harus jelas. Ndik bulih suarau putus-putus, kelaw kaba mbacaunyo, beee....riii..taaaa haa...ri...ifiii ni... (Tidak boleh suaranya putus-putus, nanti kalian membacanya, beee...riii...taa haaaa...riii...i...niii). Baca berita harus jelas, singkat, dan padat informasinya.

Pada ujaran di atas, terlihat bahwa saat guru mencoba mendefinisikan ulang apa yang dikatakan sebelumnya, guru mengubah bahasanya dari kalimat bahasa Indonesia ke dalam kalimat bahasa daerah. Tidak ada campuran atau interferensi bahasa lain dalam kalimat tersebut. Kemudian, kedua perubahan itu tidak dalam satu kalimat yang sama. Baru setelah menggunakan kalimat itu, guru beralih bahasa lagi menjadi bahasa Indonesia yang secara maknanya sama dengan ujaran sebelumnya yang diujarakan dalam bahasa daerah.

Pengelompokkan dua kalimat di atas, sebagai alih kode juga sesuai dengan pendapat Poplack (1980), yang mengatakan bahwa alih kode kemungkinan terjadi hanya pada major constituents seperti antar kalimat, klausa, bukan pada tataran konstituen yang lebih kecil seperti frasa atau kalimat. Pada ujaran (1) dan (2) pergantian bahasa terjadi dalam sebuah kalimat utuh bukan dalam tataran kata.

Selain menjelaskan tentang alih kode, beberapa ahli linguistik juga menyebutkan tentang campur kode. Dari beberapa campur kode yang telah 
disebutkan oleh beberapa ahli linguistik, penulis menyimpulkan bahwa pada prinsipnya campur kode merupakan pencampuran bahasa kedua ke dalam struktur atau kalimat bahasa pertama. Contoh campur kode yang telah dianalisis pada pengajaran bahasa Indonesia di kelas XI SMAN 6 Kabupaten Bengkulu Tengah ini dapat dilihat pada data di bawah ini.

Baiklah sesuai tugas pertemuan sebelumnya, yang mana ibu meminta tiap kalian untuk membawa berita, ada yang ndik (tidak) bawa berita?

Data (2) di atas adalah penggalan ujaran guru ketika menanyakan kepada siswa tentang tugas yang diberikan pada pertemuan sebelumnya, tetapi saat menanyakan, guru mencampurkan kata "ndik (tidak)" yang merupakan penggalan kata dalam kalimat bahasa Indonesia, dan hal inilah yang penulis lihat sebagai contoh kasus campur kode.

Sapaw (siapa) yang mau memberi komentar terhadap penampilan Agus dan Doni, Bagaimana suara mereka dalam membaca berita?

Pada data (3), guru mencampur kode pada kalimat pertanyaan, yaitu saat guru menanyakan "Siapa yang mau memberi komentar", guru mengganti kata "siapa" menjadi "sapaw", yang mengakibatkan terjadinya pergantian dari bahasa Indonesia ke dalam bahasa daerah. Kemudian, kata yang diujarkan oleh guru tersebut dalam satu susunan kalimat yang sama, karenanya ujaran di atas digolongkan dalam campur kode.

Selanjutnya dalam jenis alih kode Bloom dan Gumperz (dalam Sgall, 1992:18) tidak membedakan antara alih kode dan campur kode, karenanya hanya yang termasuk alih kode yang akan diteliti jenisnya. Berdasarkan teori Bloom dan Gumperz (dalam Sgall, 1992:18) yang telah diteliti oleh banyak ahli linguistik tentang jenis-jenis alih kode, terdapat dua jenis alih kode, yaitu situational switching dan metaphorical switching.

Dari lima kasus yang termasuk kasus alih kode, 4 kasus (80\%) termasuk situational switching dan 1 kasus (20\%) yang termasuk dalam metaphorical switching, adapun secara detail hal ini dapat dilihat pada tabel di bawah ini. 
Tabel 8. Jenis Alih Kode Situational Switching dan Metaphorical Switching pada Pembelajaran Bahasa Indonesia

\begin{tabular}{cccc}
\hline Jenis Alih Kode & Hari 1 & Hari 2 & Jumlah \\
\hline Situational Switching & 3 & 1 & 4 \\
\hline Metaphorical Switching & 1 & - & 1 \\
\hline
\end{tabular}

Berdasarkan teori yang telah ada, penulis mengartikan situational switching berdasarkan adanya perubahan situasi pembicaraan, namun tidak terdapat perubahan topik pembicaraan. Contoh nyata penggunaan situational switching, yang penulis peroleh dari hasil temuan penelitian yang telah penulis lakukan selama dua hari penelitain. Dua diantaranya adalah:

Berita itu terdiri dari beberapa jenis. Ada berita kriminal, ada berita faktual dan ada yang berisi hiburan. Dalam membaca berita intonasi suara harus jelas. Ndik bulih suarau putus-putus, kelaw kaba mbacaunyo, beee...riii..taaaa haa...ri...iiiiii ni... (Tidak boleh suaranya putus-putus, nanti kalian membacanya, beee...riii...taa haaaa...riii...i...niii). Baca berita harus jelas, singkat, dan padat informasinya.

Ada yang mau bertanya? Ndik adaw yang betanyau? (Tidak ada yang bertanya?) Kalau begitu ibu yang bertanya?

Pada contoh (3), menjelaskan bahwa saat guru menjelaskan bagaimana seharusnya seseorang membaca berita dengan menggunakan bahasa Indonesia, untuk lebih memperjelas pemahaman siswa, guru langsung mengubah bahasanya ke bahasa daerah. Pergantian bahasa itulah yang penulis lihat termasuk dalam kasus alih kode karena saat melakukan pergantian bahasa tersebut guru tidak menggabungkan kedua bahasa tersebut dalam satu kalimat.

Jenis alih kode di atas digolongkan sebagai situational switching, karena alih kode tersebut terjadi karena adanya perubahan situasi. Dalam memperjelas apa yang disampaikan guru agar siswanya mengerti, maka guru melakukan alih kode. Sedangkan pada contoh (4) setelah guru bertanya kepada siswanya apakah ada yang ingin bertanya, karena tidak ada respons dari siswa, guru langsung mengubah bahasanya menjadi bahasa daerah karena dia ingin memancing konsentrasi siswa. Oleh karena tidak ada perubahan topik ataupun perserta percakapan, maka kasus yang terjadi adalah situational switching.

Selanjutnya, penulis juga menyimpulkan bahwa metaphorical switching adalah peralihan bahasa dalam kalimat atau klausa dengan terjadinya topik 
pembicaraan, tetapi tidak adanya tambahan penutur dalam percakapan tersebut. Hal ini dapat dilihat pada data berikut ini:

Mungkin itu saja materi pelajaran kita hari ini. Ngerti nidaw kaba ni? ngantuk sajaw (Mengerti tidak kamu ini? Mengantuk saja).

Pada data (1), guru terlihat telah menggunakan metaphorical switching, karena saat menyadari siswa kurang memperhatikan apa yang disampaikan guru, guru melakukan peralihan bahasa, dari bahasa resmi menjadi bahasa lelucon ringan dalam bahasa daerah. Menurut Saville-Troike (2003:68) mengemukakan dua belas alih kode dan campur kode, tiga diantaranya dapat ditemukan pada penelitian ini. Dari 11 kasus alih kode dan campur kode yang telah disebutkan pada hasil temuan penelitian, penulis menemukan lima $(45,45 \%)$ kasus alih kode dan campur kode enam (54,54\%) dan terdapat tiga fungsi yang sesuai dengan dua belas fungsi alih kode dan campur kode yang telah disebutkan oleh SavilleTroike (2003:68), tiga kasus (27,28\%) untuk menimbulkan kelucuan, 7 kasus $(63,63 \%)$ untuk pendefinisian kembali, dan satu kasus $(9,9 \%)$ untuk kasus mempertegas perintah. Secara detail dapat dilihat pada tabel berikut ini:

Tabel 9. Frekuensi Penggunaan Fungsi Alih Kode dan Campur Kode Hari ke 1 s.d. ke 2

\begin{tabular}{llccc}
\hline & & Hari 1 & Hari 2 & Jumlah \\
\hline 1. & Menimbulkan kesan lucu & 2 & 1 & 3 \\
\hline 2. & Pendefenisian kembali & 4 & 3 & 7 \\
\hline 3. & Mempertegas perintah & 1 & - & 1 \\
\hline
\end{tabular}

Seperti disebutkan sebelumnya pada kasus alih kode dan campur kode yang terdapat dalam penelitian ini fungsinya sesuai dengan tiga fungsi alih kode dari dua belas fungsi alih kode yang menjadi dasar teori pada penelitian ini.

Dalam pelajaran bahasa Indonesia itu, ada membaca berita, membaca puisi, membaca cerita. Masing-masing ndik samaw (tidak sama), punya ciri yang berbeda.

Siapa yang bisa menjawab pertanyaan pertama? Saya bu....saya bu...kelow kudai (nanti dulu), satu-satu gantian.

Pada ujaran (3) dan (4) terdapat campur kode yang dilakukan guru antara bahasa Indonesia ke bahasa daerah dalam satu kalimat yang sama. Meskipun campur kode dianggap sebagai kesalahan bahasa, namun setelah dianalisis campur kode pada ujaran ini memiliki fungsi sebagai pendefenisian kembali yang 
digunakan guru untuk membuat siswa lebih memahami penjelasan guru. Adapun kasus alih kode yang merupakan kesengajaan guru untuk menimbulkan kesan lucu agar kemabali memunculkan semangat siswa sebelum pelajaran berakhir. Dapat dilihat pada ujaran di bawah ini.

\section{Mungkin itu saja materi pelajaran kita hari ini. Ngerti nidaw kaba ni? \\ ngantuk sajaw (Mengerti tidak kamu ini? Mengantuk saja).}

Pada ujaran guru kali ini setelah dikonfirmasi pada guru, ternyata ini adalah murni disengaja guru untuk membangkitkan semangat siswa, dengan cara menegur siswa dengan bahasa daerah. Dari seluruh data yang didapat dari analisis dan hasil wawancara yang telah dilakukan oleh peneliti, kejelian guru dalam menggunakan alih kode dan campur kode sesuai dengan fungsinya sangat terlihat jelas pada pembelajaran bahasa Indonesia. Kejelian tersebut dapat menunjukkan bahwa tingkat intelektualitas guru yang bersangkutan cukup tinggi, juga kemampuan berbahasa Indonesia yang sudah baik karena dari sekian banyaknya ujaran yang terjadi selama dua hari penelitian, guru hanya menggunakan 11 kasus alih kode dan campur kode. Sesuai dengan kajian sosiolingistik, ternyata tingkat intelektualitas dan penguasaan bahasa sasaran yang baik dapat menyebabkan minimnya penggunaan alih kode dan campur kode dalam pengajaran bahasa Indonesia.

\section{Simpulan}

Dari hasil penelitian dan pembahasan, dapat disimpulkan alasan guru menggunakan alih kode dan campur kode pada pengajarannya, antara lain karena (1) guru berusaha untuk mendefinisikan kembali situasi yang telah disebutkan sebelumnya (redefinition), agar siswa lebih memahami maksud dari ucapannya, (2) guru berusaha mencairkan suasana kelas yang monoton dengan menggunakan alih kode dan campur kode untuk menimbulkan kesan lucu, dan (3) guru harus mempertegas perintahnya (strengthen command) agar siswa lebih mengerti bahwa hal yang diperintahkan guru harus diikuti.

Kemudian, dari hasil penelitian ini terdapat gejala sosial yang mendasari banyak atau sedikitnya kasus alih kode dan campur kode dalam pengajaran 
bahasa Indonesia adalah tingkat kemampuan berbahasa dari guru yang mengajarkan bahasa tersebut. Semakin tinggi kemampuan berbahasanya, maka akan semakin sedikit kasus alih kode itu terjadi, begitu juga sebaliknya. Hal ini dapat diwakili oleh kemampuan berbahasa guru yang mengajar yang menjadi objek dari penelitain ini. Ketepatan penggunaan dan pemilihan bahasa pada saat melakukan pengajaran bahasa Indonesia oleh guru ini dapat dilihat minimnya dan ketepatan alasan penggunaan alih kode dan campur kode.

\section{Daftar Pustaka}

Coulmas, F (ed). (2005). The Handbook of Sociolinguistics. USA: Blackwell Publishers. Blackwell Reference Online.

Fasold, R. (1984). The Sociolinguistics of Society. Oxford: Basil Blackwell.

Finegan, E. (2004). Language: Its Structure and Use. Massachussets: Thomas Corp.

Hoffman, C. (1991). An Introduction to Bilingualism. London: Longman.

Koentjono, D. (1990). Dasar-Dasar Linguistik Umum. Jakarta: Fakultas Sastra UI.

Poplack, Shanna. (1980). Code Switching: Anthropological and Sociolinguistic Perspectives. Berlin/New York: Mounton de Gruyter.

Rulyandi, Muhammad Rohmadi \& Sulistyo, Edy Tri. (2014). Alih Kode dan Campur Kode dalam Pembelajaran Bahasa Indonesia di SMA. Paedagogia, 17(1), pp. 27-39.

Saville-Troike, M. 2003. The Ethnography of Communication: An Introduction. Blackwell Publishing Ltd.

Suwandi, Sarwiji. (2010). Serba Linguistik: Mengupas Berbagai Praktik Bahasa. Surakarta: Universitas Sebelas Maret Press.

Wardhaugh, R. (2002). An Introduction to Sociolinguistics. Massachussets: Blackwell. 